\title{
Tree Recruitment Limitation by Introduced Snowshoe Hares, Lepus americanus, on Kent Island, New Brunswick
}

\author{
Trevor S. Peterson, Akane Uesugi, and John Lichter \\ Biology Department and Environmental Studies Program, 6500 College Station, Bowdoin College, Brunswick, Maine 04011 \\ USA
}

Peterson, Trevor, Akane Uesugi, and John Lichter. 2005. Tree recruitment limitation by introduced Snowshoe Hares, Lepus americanus, on Kent Island, New Brunswick. Canadian Field-Naturalist 119(4): 569-572.

Species introductions often have negative consequences for native plant and animal communities of islands. Herbivores introduced to islands lacking predators can attain high population densities and alter native plant communities by selective consumption of palatable plants. We examined the legacy of the 1959 introduction of Snowshoe Hares (Lepus americanus) to Kent Island, New Brunswick, by reconstructing a history of tree recruitment on Kent Island and on nearby Outer Wood Island, which lacks Snowshoe Hares. Tree-ring records show pronounced recruitment peaks associated with farm abandonment in the 1930s for Kent Island and in the 1950s for Outer Wood Island. Following the introduction of Snowshoe Hares to Kent Island, tree recruitment plummeted and has remained low ever since. In contrast, trees continued to establish throughout the latter $20^{\text {th }}$ century on Outer Wood Island. The high rates of seedling mortality on Kent Island associated with Snowshoe Hare browsing coupled with high rates of canopy tree mortality threaten to degrade severely the forest of this important seabird nesting sanctuary.

Key Words: Snowshoe Hare, Lepus americanus, invasive species, tree recruitment limitation, Kent Island seabird sanctuary, New Brunswick.

Introduced herbivores often cause great damage to island ecosystems and potentially result in plant species extinction (Van Vuren and Coblentz 1987; Moran 1996; Coblentz 1990). The absence of significant predators allows introduced herbivores to reach high population densities and exert intense grazing pressure on poorly defended plants (Krebs et al. 2002; Donlan et al. 2002). Because woody plants are most vulnerable to browsing during their early stages of development and growth (Clark et al. 1999; Liang and Seagle 2002), intense browsing may limit tree regeneration and allow less palatable species to proliferate (Rossow et al. 1997; Heinen and Currey 2000). Shifts in plant species dominance resulting from intense herbivory have been demonstrated in tropical, temperate, and boreal island ecosystems and indicate the community-level impacts of herbivore introductions or predator removal from islands (McLaren and Peterson 1994; Chouinard and Filion 2001; Terborgh et al. 2001).

In 1959, Snowshoe Hares (Lepus americanus) colonized Kent Island, an 80-hectare island in the Bay of Fundy, New Brunswick, following intentional introduction to Hay Island, a nearby island connected to Kent Island at low tide (C. Huntington, personal communication). Subsequently, estimates of the hare population in various years have ranged between 50 and 500 individuals based on mark-recapture techniques $(\mathrm{N}$. Wheelwright, Bowdoin College; personal communication). Snowshoe Hares are generalist herbivores that feed on a variety of grasses and shrubs during the summer, but on tree bark, foliage, and twigs during the winter (de Vos 1964). Diet selection studies have demon- strated that hares preferentially browse deciduous species, but may rely on conifers during winter or during periods of high population density if preferred forage is not available (Aldous and Aldous 1944; de Vos 1964; Parker 1984). Snowshoe Hares often avoid White Spruce (Picea glauca) when other browse is available, presumably because of high levels of camphor in the foliage (Sinclair et al. 1988; Rangen et al. 1994; Heinen and Currey 2000). The concentration of secondary compounds in vegetation may also influence diet selection (Fox and Bryant 1984; Rousi 1997; Rodgers and Sinclair 1997). Paper Birch (Betula papyrifera) saplings, for example, can effectively deter Snowshoe Hare browsing with high concentrations of secondary compounds (Bryant 1981).

Although Snowshoe Hare browsing of trees is generally limited to heights less than $1 \mathrm{~m}$, hares are important herbivores in boreal forests, and considerable damage to seedlings and saplings in forest plantations has been attributed to hares (Aldous and Aldous 1944; Holl and Quiros-Nietzen 1999; Rao et al. 2003). Based on Kent Island's high population of Snowshoe Hares and on observations of intense browsing of tree seedlings, we hypothesized that browsing by hares effectively halted tree recruitment since their introduction in 1959. To document the impacts of hare browsing on Kent Island, we reconstructed a tree recruitment history based on tree-ring records for Kent Island and for nearby Outer Wood Island, which lacks Snowshoe Hares. We also compared current tree recruitment rates on the two islands by estimating seedling and sapling densities in randomly located plots. 


\section{Study Area}

Kent Island is at the southern end of the Grand Manan archipelago in the Bay of Fundy, New Brunswick $\left(44^{\circ} 35^{\prime} \mathrm{N}, 66^{\circ} 46^{\prime} \mathrm{W}\right)$. The island is an important nesting area for Leach's Storm Petrel (Oceanodroma leucorhoa) and Savannah Sparrow (Passerculus sandwichensis). Since 1935, Bowdoin College of Brunswick, Maine, has operated a biological station on Kent Island. In 1959, Snowshoe Hares were intentionally introduced to nearby Hay Island, and soon thereafter crossed the tidally exposed land bridge to Kent Island. Hare populations have persisted on both islands since that time. Muskrats (Ondatra zibethicus) were introduced earlier in 1941 (Huntington 1956). The forest community contains Balsam Fir (Abies balsamea), White Spruce, Red Spruce (Picea rubens), Yellow Birch (Betula allegheniensis), Heart-leaved Birch (Betula cordifolia), and Mountain Ash (Sorbus americanus). A mixed forest dominated by White Spruce and Balsam Fir covers approximately two-thirds of the northern half of the island, whereas grassland covers the southern half of the island. In the early $20^{\text {th }}$ century, much of the grassland was either cultivated or used for hayfield and pasture (Gleason 1937). Today seedlings and saplings of any tree species are rare on Kent Island. Those that are found show a pronounced browse line up to $60 \mathrm{~cm}$ in height. Canopy trees are suffering high rates of mortality for unknown reasons, and the gaps formed by tree death and windthrow are rapidly colonized by Red Raspberry (Rubus idaeus) and Wood Fern (Dryopteris spinulosa) rather than trees.

Outer Wood Island $\left(44^{\circ} 37^{\prime} \mathrm{N}, 66^{\circ} 49^{\prime} \mathrm{W}\right)$ is approximately $6 \mathrm{~km}$ northwest of Kent Island. Forest covers its central area, which is surrounded by grasslands similar to Kent Island. White Spruce and Red Spruce are the dominant canopy species with Balsam Fir, Yellow Birch, and Mountain Ash important locally. Outer Wood Island lacks Snowshoe Hares, but, like Kent Island, has a large introduced Muskrat population. Outer Wood Island was used for sheep pasture throughout the early and middle $20^{\text {th }}$ century (Ingersoll 1991).

\section{Methods}

In March 2002, an attempt to eradicate the Snowshoe Hare population on Kent Island was initiated, which resulted in a reasonably accurate population estimate. Eradication efforts have continued up to the present. Prior to the attempted hare eradication, we counted hare pellets in 132 plots $(1 \mathrm{~m} \times 1 \mathrm{~m})$ randomly located within forests on Kent Island to document hare distribution on the island, as described by Krebs et al. (2001).

To describe the composition of the forests, we examined trees occurring along the length of nine randomly located $2 \mathrm{~m} \times 50 \mathrm{~m}$ transects on each island. Canopy trees were identified to species and their diameter-atbreast-height (DBH) was recorded. To develop treerecruitment histories, we collected increment cores from White Spruce, Red Spruce, and Balsam Fir trees in nine randomly chosen circular plots on each island. Within each plot, the ten trees nearest the center and greater than $5-\mathrm{cm} \mathrm{DBH}$ were cored at a height ranging between 30 and $50 \mathrm{~cm}$ from the ground. The species identity and DBH were recorded for all cored trees. We also took advantage of numerous treefalls that occurred during the winter of 2000-2001 by collecting basal discs from 33 trees. The discs and cores were sanded smooth, and the rings were counted using a binocular Leica dissecting microscope and a Velmex tree-ring measuring system. To account for early growth of the trees, we added five years to the tree-age estimates of basal discs and ten years to the estimates of increment cores (DesRochers and Gagnon 1997; Parent et al. 2000).

On both islands, established seedlings and saplings were quantified in three $78.5-\mathrm{m}^{2}$ (i.e., 5 -m radius) sample plots, located $25 \mathrm{~m}$ apart along each 50-m transect. Seedlings were defined as any stem less than $1 \mathrm{~m}$ in height and saplings were defined as stems greater than $1 \mathrm{~m}$ in height and having a DBH less than $5 \mathrm{~cm}$. Height measurements and extent-of-browsing estimates were recorded on isolated White Spruce seedlings on Kent Island and Outer Wood Island.

\section{Results}

The density of Snowshoe Hare pellets on Kent Island was $47.1( \pm 6.2) / \mathrm{m}^{2}$ and ranged between 6 and 110 pellets $/ \mathrm{m}^{2}$. Pellet densities were not significantly correlated with seedling abundances. No pellets were found on Outer Wood Island. After one month of hunting in early 2002, 275 Snowshoe Hares had been killed on Kent Island, indicating a minimum density of 3.43 hares per hectare. The hare population was not eliminated during this period of hunting, and the population has subsequently rebounded, although not to its maximum level. Eradication efforts are scheduled to continue in winter 2005-2006.

The recruitment histories of canopy trees of the two islands show patterns of reforestation following farm abandonment and cessation of livestock grazing in the mid-20 $0^{\text {th }}$ century (Ingersoll 1991). Consistent with the timing of land-use change, peak tree recruitment occurred during the 1930s on Kent Island and during the 1950s on Outer Wood Island (Figure 1). On Kent Island, tree recruitment remained high through the 1940s but declined precipitously in the 1950s, whereas tree recruitment on Outer Wood Island was relatively high throughout the 1960s and 1970s, two decades after its peak (Figure 1).

The abundances of saplings and established seedlings (i.e., $>2$ yrs old) reveal the disparity in recent tree recruitment on the two islands. Sapling abundance of all tree species was much greater on Outer Wood Island than on Kent Island (OWI $=29.4 \pm 13.3$; $\mathrm{KI}=0.1 \pm 0.1 ; \mathrm{df}=43 ; \mathrm{t}=2.71 ; P=0.01$ ) (Figure 2). The abundance of established seedlings was similarly 


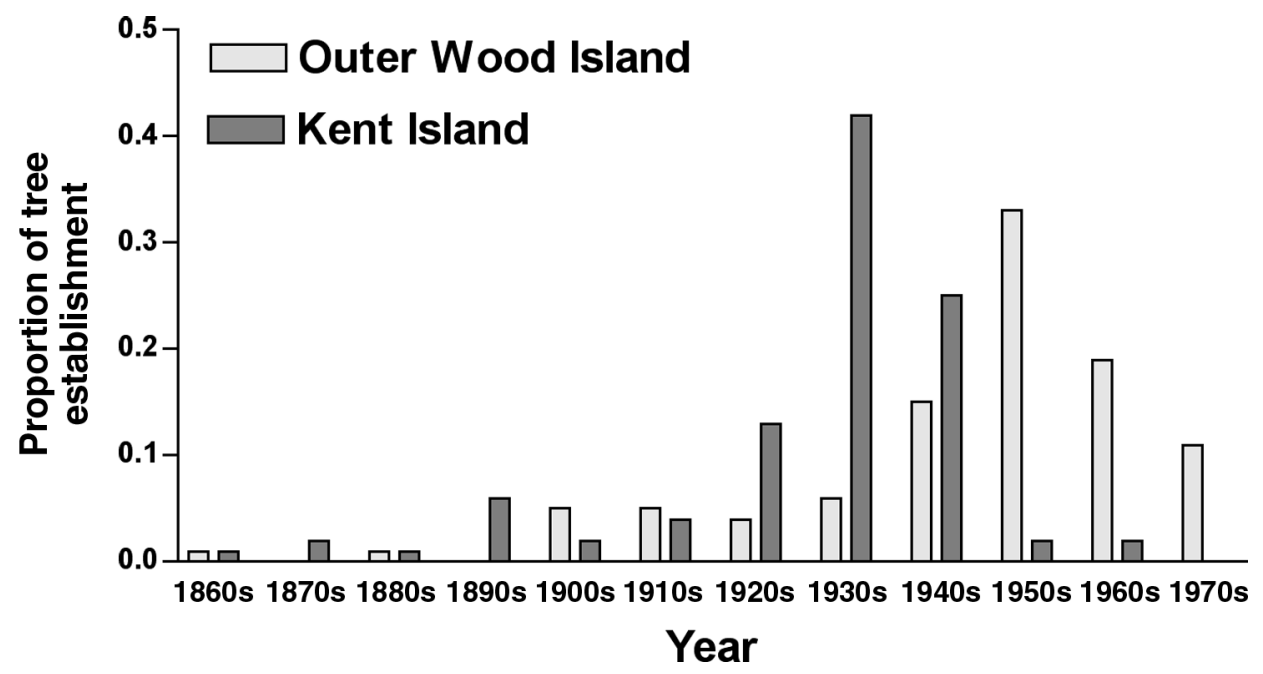

FIGURE 1. Tree recruitment history for Kent Island and Outer Wood Island, New Brunswick derived from tree-ring records. Data given as the proportion of the total number of canopy trees cored for each decade between 1860 and 1980. Snowshoe Hares were introduced to Kent Island in 1959.

much greater on Outer Wood Island than on Kent Island $(\mathrm{OWI}=14.1+3.5 ; \mathrm{KI}=0.3+0.2 ; \mathrm{df}=43 ; \mathrm{t}=3.17$; $P=0.003)$. All of the 58 spruce seedlings and saplings examined on Kent Island showed visible signs of browsing. Of these 58 trees, 40 were less than one meter in height, and 18 between 1 and $2 \mathrm{~m}$ tall. Of the 40 less than $1 \mathrm{~m}$ in height, 24 were missing their apical meristem, whereas of the 18 ranging between 1 and $2 \mathrm{~m}$ in height, only one had its apical meristem browsed. On Outer Wood Island, apical stems were present on all 60 of the seedlings sampled, and little or no evidence of browsing was present.

\section{Discussion}

The history of tree recruitment on Kent Island and Outer Wood Island demonstrates the long-term, negative effects of intense Snowshoe Hare browsing on tree recruitment in an island ecosystem lacking mammalian predators. The precipitous decline of tree recruitment on Kent Island during the 1950s suggests that the Snowshoe Hare population increased rapidly and that few established tree seedlings survived the onset of hare browsing. While we have no sequential estimates of the hare population density, the lack of saplings and established seedlings suggests that hares were numerous enough to limit tree recruitment severely throughout the past forty-five years. Sustained browsing pressure can cause a shift toward less palatable species (McLaren and Peterson 1994; Heinen and Currey 2000; Terborgh et al. 2001). Because all tree species on Kent Island are palatable to Snowshoe Hares, a shift to less palatable species would result in loss of forest. Currently as canopy trees die, Wood Fern and Red Raspberry replace them. A dense cover of Wood

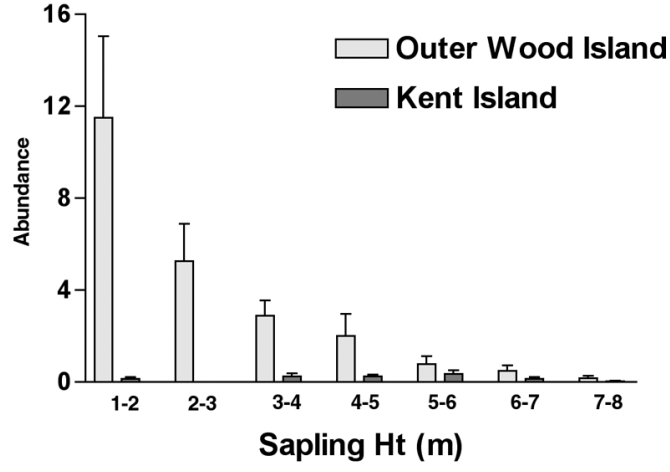

FIGURE 2. Tree sapling abundance for Kent Island and Outer Wood Island, New Brunswick, given for height classes.

Ferns probably also limits tree recruitment as Wood Ferns have been shown to limit the photosynthetic capabilities of coniferous seedlings (Starostina 1988).

This study contributes to a growing body of research documenting pronounced ecosystem-level consequences of herbivore introductions to islands (e.g., Van Vuren and Coblentz 1987; Donlan et al. 2003). Because Snowshoe Hares are the only mammalian herbivores that browse trees on Kent Island, they are responsible for all of the browsing damage since their introduction. If the current hare eradication efforts are not successful, it is likely that this forest will become severely degraded in the future as the canopy trees reach senescence. This outcome may negatively affect the suitability of the island as nesting habitat for Leach's Storm Petrels, 
whose nest sites are currently concentrated in the forested portions of the island. This would be unfortunate, because Kent Island provides vital and well-documented nesting habitat for Leach's Storm Petrel (Gross 1935; Griffin 1940; Huntington 1956, 1959). Successful eradication of Snowshoe Hares from Kent Island would provide a valuable opportunity to document whether removal of the dominant herbivore will allow the forest community of the island to recover from nearly half a century of suppressed tree recruitment.

\section{Acknowledgments}

We sincerely thank Nat Wheelwright, Barry Logan, and Chuck Huntington for thoughtful comments on this manuscript, and Sarah Rodgers, Jaret Reblin, and Peter Hill for help in the field. This is contribution number 154 from the Kent Island Scientific Station.

\section{Literature Cited}

Aldous, C. M., and S. E. Aldous. 1944. The snowshoe hare - a serious enemy of forest plantations. Journal of Forestry 42: 88-94.

Bryant, J. P. 1981. Phytochemical deterrence of snowshoe hare browsing by adventitious shoots of four Alaskan trees. Science 213: 889-890.

Chouinard, A., and L. Filion. 2001. Detrimental effects of white-tailed deer browsing on balsam fir growth and recruitment in a second-growth stand on Anticosti Island, Québec. Écoscience 8: 199-210.

Clark, J. S., B. Beckage, P. Camill, B. Cleveland, J. HilleRisLambers, J. Lichter, J. McLachlan, J. Mohan, and P. Wycoff. 1999. Interpreting recruitment limitation in forests. American Journal of Botany 86: 1-16.

Coblentz, B. E. 1990. Exotic organisms: a dilemma for conservation biology. Conservation Biology 4: 261-265.

DesRochers, A., and R. Gagnon. 1997. Is ring count at ground level a good estimation of black spruce age? Canadian Journal of Forest Research 27: 1263-1267.

de Vos, A. 1964. Food utilization of snowshoe hares on Manitoulin Island, Ontario. Journal of Forestry 62: 238-244.

Donlan, C. J., B. R. Tershy, and D. A. Croll. 2002. Islands and introduced herbivores: conservation action as ecosystem experimentation. Journal of Applied Ecology 39: 235246.

Donlan, C. J., B. R. Tershy, K. Campbell, and F. Cruz. 2003. Research for requiems: the need for more collaborative action in eradication of invasive species. Conservation Biology 17: 1850-1851.

Fox, J. F., and J. P. Bryant. 1984. Instability of the snowshoe hare and woody plant interaction. Oecologia 63: 128-135.

Gleason, H. A. 1937. A botanical report on Kent's Island. Annual Report of the Bowdoin Scientific Station 3: 27-29.

Griffin, D. R. 1940. Homing experiments with Leach's petrels. Auk 57: 61-74.

Gross, W. A. O. 1935. The life history cycle of Leach's petrel (Oceanodroma leucorhoa) on the outer sea islands of the Bay of Fundy. Auk 52: 382-399.

Heinen, J. T., and R. C. D. Currey. 2000. A 22-year study on the effects of mammalian browsing on forest succession following a clearcut in northern lower Michigan. American Midland Naturalist 144: 243-252.

Holl, K. D., and E. Quiros-Nietzen. 1999. The effect of rabbit herbivory on reforestation of abandoned pasture in southern Costa Rica. Biological Conservation 87: 391-395.
Huntington, C. E. 1956. The Bowdoin Scientific Station. Maine Field Naturalist 12: 2-9.

Huntington, C. E. 1959. Notes on the birds of Grand Manan Archipelago. Maine Field Naturalist 15: 2-8.

Ingersoll, L. K. 1991. Wings over the Sea. Goose Lane Editions. Fredericton, New Brunswick.

Krebs, C. J., R. Boonstra, V. Nams, M. O'Donahue, K. E. Hodges, and S. Boutin. 2001. Estimating snowshoe hare population density from pellet plots: a further evaluation. Canadian Journal of Zoology 79: 1-4.

Krebs, C. J., T. N. Zimmerling, C. J. Jardine, K. A. Trostel, A. J. Kenney, S. Gilbert, and E. J. Hofer. 2002. Cyclic dynamics of snowshoe hares on a small island in the Yukon. Canadian Journal of Zoology 80: 1442-1450.

Liang, S.-Y., and S. Seagle. 2002. Browsing and microhabitat effects on riparian forest woody seedling demography. Ecology 83: 212-227.

McLaren, B. E., and R. O. Peterson. 1994. Wolves, moose, and tree rings on Isle Royale. Science 266: 1555-1558.

Moran, R. 1996. The flora of Guadalupe Island, Mexico. Memoirs of the California Academy of Sciences 19: 1190.

Parent, S., H. Morin, and C. Messier. 2000. Effects of adventitious roots on age determination in balsam fir (Abies balsamea) regeneration. Canadian Journal of Forest Research 30: 513-518.

Parker, G. R. 1984. Use of spruce plantations by snowshoe hare in New Brunswick. The Forestry Chronicle 60: 162166.

Rangen, S. A., A. W. L. Hawley, and R. J. Hudson. 1994. Relationship of snowshoe hare feeding preferences to nutrient and tannin content of four conifers. Canadian Journal of Forest Research 24: 240-245.

Rao, S. J., G. R. Iason, I. A. R. Hulbert, and D. A. Elston. 2003. The effect of sapling density, heather height and season on browsing by mountain hares on birch. Journal of Applied Ecology 40: 626-638.

Rodgers, A. R., and A. R. E. Sinclair. 1997. Diet choice and nutrition of captive snowshoe hares (Lepus americanus): interactions of energy, protein, and plant secondary compounds. Écoscience 4(2): 163-169.

Rossow, L. J., J. P. Bryant, and K. Kielland. 1997. Effects of above-ground browsing by mammals on mycorrhizal infection in an early successional taiga ecosystem. Oecologia 110: 94-98.

Rousi, M. 1997. Variation in resistance of forest trees to hare (Lepus sp.) browsing. Gibier Faune Sauvage, Game Wildlife 14: 281-293.

Sinclair, A. R. E., M. K. Jogia, and R. J. Andersen. 1988. Camphor from juvenile white spruce as an important antifeedant for snowshoe hares. Journal of Chemical Ecology 14: $1505-1514$

Starostina, K. F. 1988. Photosynthesis of Picea-Abies Pinaceae plantlets in an Oxalis-wood-fern spruce forest. Botanicheskii Zhurnal (Leningrad) 73: 1146-1151.

Terborgh, J., L. Lopez, P. V. Nuñez, M. Rao, G. Shahabuddin, G. Orihuela, M. Riveros, R. Ascanio, G. H. Adler, T. D. Lambert, and L. Balbas. 2001. Ecological meltdown in predator-free forest fragments. Science 294: 1923-1926.

Van Vuren, D., and B. E. Coblentz. 1987. Some ecological effects of feral sheep on Santa Cruz Island, California, USA. Biological Conservation 41: 253-268.

Received 11 January 2005

Accepted 26 September 2005 